Editorial

\title{
A global journal with Central European roots: a vision for the JIRD
}

Journal of International Relations and Development (2012) 15, 317-320. doi:10.1057/jird.2012.16

The JIRD is a global journal with Central European roots. We have established a diverse editorial team of scholars from Europe and North America linked first by a commitment to publish highest quality scholarship in international relations (IR) and development, broadly conceived, regardless of substantive or methodological focus; and second by a common awareness of the contribution the Central and East European (CEE) experience can make to the study of international politics. We envision the JIRD as a globally relevant journal with a CEE touch. This does not mean dealing primarily with CEE themes, although the region will naturally remain more strongly in focus than in comparable IR journals. More profoundly, it means nurturing both CEE IR scholarship and also the broader transnational scholarly context in which it develops.

In the first three editorial periods, Zlatko Šabič, Stefano Guzzini and Patrick T. Jackson led rigorous and highly professional editorial teams. Thanks to their skilful leadership, the JIRD was established as a forum for innovative and highquality scholarship and began to fulfil its mandate as the official journal of the Central and East European International Studies Association (CEEISA). It also achieved an Social Science Citation Index (SSCI) listing. Entrusting the editorship into the hands of excellent scholars with academic backgrounds from Western universities was a good way of providing the journal with ideational resources, experience and academic contacts necessary for ensuring high levels of academic rigour and quality. This was needed in the late 1990s when the scholarly communities in political science and IR in CEE were in a period of transition and/or establishment and there were very few scholars in the region able and willing to take on the complex task of establishing and editing a globally competitive academic journal. Today, however, the research milieu in IR and related fields in $\mathrm{CEE}$ countries has matured. This results from at least three factors.

First, a new generation of scholars with $\mathrm{Ph} . \mathrm{D}$. degrees and research experience from top-ranking Western institutions has taken on positions in CEE universities and research institutes. Second, a significant number of Western scholars who have spent time at CEE universities throughout the last two decades have returned to Western universities and continue to develop 
research programmes related to $\mathrm{CEE}$ and IR. Third, research in the CEE countries has gone through important scholarly debates on the character of IR scholarship in their country and in the region (e.g., see the forum debate in $J I R D$ edited by Petr Drulák 2009a); on the nature of their specific 'national' contributions to global IR scholarship (e.g., the debate initiated by Drulák in the Czech journal Mezinárodni vztahy (Drulák 2009b); and on the role of Central Europe regional and global IR (e.g., Šabič and Drulák 2012).

Today, CEE scholarship on international politics is increasingly re-connected to global academic debates and is more self-aware. The new editorial team therefore includes scholars with Western, CEE and mixed academic backgrounds and expertise, with previous editorial experience and with close links throughout the CEE and global IR scholarly community. This editorial change contributes a slightly greater degree of regional 'ownership' to the journal, while simultaneously keeping it firmly connected to and competitive within global IR scholarship.

Under our leadership, the JIRD will continue to host social-scientific debates on international politics with no pre-specified geographic, theoretical or methodological focus. We continue to subscribe to the editorial philosophy of the previous editorial team, which is built on a Weberian understanding of the purpose of social-scientific enquiry as a systematic 'analytical ordering of empirical actuality' (Jackson 2008: 221). We value manuscripts that help to further our understanding of the world around us, but are not restrictive in any theoretical and methodological sense beyond this basic premise. We do, of course, seek groundbreaking contributions in terms of methodologies, theories and substantive issues addressed.

The journal also continues to take special interest in CEE. It is meant to function as an open space for dialogue and debate of international issues of relevance in the CEE region and beyond, such as: CEE and its role in global politics; foreign policy approaches of CEE countries; integration processes in the European Union and elsewhere; EU foreign policy; change dynamics in the transatlantic security architecture; democratic and market transformation; institutional change and the transformation of political regimes; the challenges of post-communist transformation and development within an international context; variety of post-communist capitalisms; institutional involvement in the CEE region (including in the issue-areas of human rights, democracy, rule of law); and CEE involvement in international institutions. The CEE experience is also relevant in relation to development studies. The region simultaneously: provides a development model for the global south (which can be both embraced and critiqued); as a part of Europe is increasingly a source of international development assistance and global humanitarian involvement; and is, itself, still developing and transforming. These facts support a multifaceted and open understanding of development, which should also underpin contributions to the JIRD. We also encourage contributions 
analyzing the links, or the lack of them, between different IR communities and approaches, and the effects of such (lacks of) linkages.

A particular challenge for the JIRD so far has been to attract top-quality work from scholars affiliated with universities in CEE. So far, CEE scholars have authored about 10 per cent of the journal's articles. This is on par with scholars from Germany, and represents the third largest group of contributors following scholars affiliated in the United States and the United Kingdom. This percentage should be higher if the JIRD is indeed to become the premier forum for scholarly debate on international politics in CEE. Hence, we particularly encourage contributions by authors affiliated in CEE. We will carefully work with these authors to improve highly promising manuscripts, through a rigorous and supportive editorial process.

Moreover, the journal encourages debates on the ideational foundations of the study of IR. This includes efforts to re-discover ideational approaches developed in CEE contexts before the decades of communist rule, as well as to explore the relevance and connecting points of current global theorizing in IR in relation to CEE experiences. In this way, the JIRD will contribute to the nurturing of CEE thinking on international politics, of course by including not only contributions by CEE authors but by authors from a variety of backgrounds and disciplines with relevance for IR in CEE and beyond.

Our most important target for the journal is to continue to enhance its reputation as a distinctive outlet for original and rigorous research in international relations and development. We are excited to work with our authors and reviewers over the next several years to make this vision a reality.

\section{References}

Drulák, Petr, ed. (2009a) 'International Relations in Central and Eastern Europe Forum', Journal of International Relations and Development 12(2): 168-220.

Drulák, Petr (2009b) 'Přestaòme doháòet, začněme tvořit! Budoucnost českého oboru mezinárodních vztahů (Forget Emulation, and Start Creating! The Future of Czech IR Research)', Mezinárodni vztahy 44(3): 95-109.

Jackson, Patrick Thaddeus (2008) 'The Editorial Vision of the Third Regime', Journal of International Relations and Development 11(3): 219-221.

Šabič, Zlatko and Petr Drulák, eds. (2012) Regional and International Relations of Central Europe, Basingstoke: Palgrave.

Jozef Bátora

Comenius University, Bratislava

Annette Freyberg-Inan University of Amsterdam, Amsterdam, The Netherland 
John Gould Colorado College, Colorado, USA

Nik Hynek Institute of International Relations, Prague

David Karp University of Glasgow, Glasgow, UK

Petra Roter University of Ljubljana, Ljubljana, Slovenia 